\title{
SELF-ESTEEM AND ITS IMPACT ON ACADEMIC ACHIEVEMENT AMONG ADOLESCENTS IN AND AROUND LUCKNOW (U.P.) INDIA
}

\author{
Vijay Rana* \\ Research Scholar, Amity Institute of Behavioral \& Allied Sciences, \\ Amity University, Lucknow, Uttar Pradesh, India \\ Dr. Pragyan Dangwal \\ Assistant Professor, Amity Institute of Behavioral \& Allied Sciences, \\ Amity University, Lucknow, Uttar Pradesh, India \\ *Corresponding Author
}

\begin{abstract}
What is Self Esteem and academic achievement? What is the role of it in development of young guns? Many teens, their teachers, their parents, and others think so, and many adults recall adolescence as a time of increasingly heightened selfscrutiny and greatly fluctuating self-esteem. But the answer is not entirely clear, as selfesteem is a subjective state, and therefore very hard to measure. Academic achievement describes academic outcomes that indicate the extent to which a student has achieved their learning goals. Academic achievement was inferred from the school performance records. Academic achievement may refer to completing educational benchmarks such as a bachelor's degree. Academic achievement is often measured through examinations or continuous assessments. An adolescent may have different levels of self-esteem in different domains such as social, scholastics, athletics, appearance, and general conduct and actions. This research study done to measures Self Esteem and Academic Achievement in Adolescents of in and around Lucknow Uttar Pradesh. 300 Adolescents age group 14-17 years from different schools of Lucknow were taken for the assessment. Study was done with the help questioners having four different informative sections including personal data sheet and few major perameters to conclude the research. The findings are discussed and implications for practice and further research given.
\end{abstract}

Key Words: Academic achievement, Adolescents, Self esteem, academic achievement 
Cite this Article: Vijay Rana, Pragyan Dangwal, Self-Esteem and its Impact on Academic Achievement among Adolescents in and around Lucknow (U.P.) India, International Journal of Management, 11(12), 2020, pp 3430-3438.

https://iaeme.com/Home/issue/IJM?Volume $=11 \&$ Issue $=12$

\section{INTRODUCTION}

The word adolescence is coined from the Latin verb 'adolescere' which means 'to grow in to maturity'. Therefore adolescence is a phase where in an individual grows to be a responsible adult. Peterson (1988) has described adolescence as a phase of life beginning in biology and ending in society. Adolescence, thus is a very important phase where in the experiences and learning of an individual form a base for what an individual will be like when he grows up to be an adult.

\subsection{Self - Esteem}

The "self" part of self-esteem pertains to the values, beliefs and attitudes that we hold about ourselves. The "esteem" part of self-esteem describes the value and worth that one gives to oneself. Self-esteem is typically viewed as a continuous dimension ranging from high to low people with high self-esteem feel very positive about themselves, whereas those with low selfesteem feel ambivalent or uncertain about themselves. Truly negative self-evaluations or selfhatred are unusual and typically found only in clinical populations (Brown et al., 2001; Leary and MacDonald, 2003). This global evaluation is the most common definition of self esteem, and is considered relatively stable (i.e., an individual can be said to have a dispositional level of self-esteem). It is also sometimes referred to as self-worth, self-regard, or self evaluation all of which have the same essential meaning. The construct of self-esteem has a long and checkered history within the discipline of psychology. At its highest potential, academic achievement involves a student's psychological investment in learning, comprehending, and mastering knowledge (Suh \& Suh, 2006). However, the most overt, public, visible indicators of academic achievement are school marks or grades. These are greatly valued as a determinant of one's success in academics (Rosenberg et al., 1985). The ultimate lowest measure of academic achievement is that of a "drop-out" (Suh \& Suh, 2006). Crocker and Luhtanen (2003) gave self-esteem an ambiguous definition. For some, it could be dependent on being attractive, loved, or good at school, while for others it could be based on being virtuous, powerful, or selfreliant. These beliefs may determine how much time is spent on certain behaviors based on the importance these behaviors may hold. For example, students in their freshmen year at college who value academics most spend more time studying, while students who base their self-esteem on appearance spend more time exercising and grooming (Crocker \& Luhtanen). Self-Esteem in adolescents is important as it allows them to try new things, take healthy risks and solve problems. In turn, their learning and development will be productive and will set them up for a healthy and positive future. A young person with healthy self-esteem is more likely to display positive behavioral characteristics, such as acting independent and mature

- Taking pride in their accomplishments/achievements

- Accepting frustration and dealing with it responsibly

- Trying new things and challenges

- Helping others when possible

Academic achievement describes academic outcomes that indicate the extent to which a student has achieved their learning goals. Academic achievement is commonly measured through examinations or continuous assessments but there is no general agreement on how it is best evaluated or which aspects are most important—procedural knowledge such as skills or 
declarative knowledge such as facts. Furthermore, there are inconclusive results over which individual factors successfully predict academic performance, elements such as test anxiety, environment, motivation, and emotions require consideration when developing models of school achievement. Now, schools are receiving money based on its student's academic achievements. A school with more academic achievements would receive more money than a school with less achievement.

Academic achievement: In a number of ways, academic achievement is measured. The most widely used, the rate of high school completion is the measure cited. Statistics on grades, standardized test results, absenteeism, suspensions and expulsions, and the number of students who were kept back are also available. (Lynn Magdol).

\section{REVIEW OF LITERATURE}

Ashra, B. K. \& Jogsan, Y. A. (2013). Study on "locus of control and self-esteem among youth male and female." Result show that there was no significant difference in locus of control and self-esteem with respect to both youth male and female. While the correlation between locus of control and self-esteem reveals 0.54 positive correlation.

Bagheri, M. S. \& Faghin, M. (2012) study on "the relationship between self-esteem, personality type and reading comprehensive of Iranian EFL students." Result of the study revealed that there was a positive relationship between overall self-esteem and reading comprehension, and overall self-esteem and personality type, in general. Likewise, positive relationship between situational and task self-esteem with reading comprehension were shown but there wasn't a significant relationship between global self-esteem and reading comprehension. Also the relationship between personality type and reading comprehension was insignificant.

Dudhatra, R. \& Jogsan, Y. A. (2012) study on "self-esteem and academic achievement among P.G. and U.G. students." Result show that significant difference in self-esteem and academic achievement among U.G. and P.G. students. U.G. student have high self-esteem and academic achievement as compare P.G. students. While correlation between self-esteem and academic achievement is 0.82 positive correlation.

Hosogi, M., Okada, A., Pujil, C., Watanable, K. and Noguchi, K. (2012) study on "importance and usefulness of evaluating self-esteem in children." They show that the development of children's self-esteem is heavily influenced by their environment, that is, their homes, neighborhoods and schools. Child with damaged self-esteem are at risk of developing psychological and social problems, which hinders recovery from low self-esteem. Thus, to recover low self-esteem, it is important for children to accumulate a series of successful experiences to create a positive concept of self. Evaluating children's self-esteem can be an effective method for understanding their past and present circumstances and useful to treat for children with psychosomatic disorder.

Bhattacharjee, A. (2011) study on "impact of gender and community on locus of control and self-esteem among undergraduate students." Findings revealed significant impact of gender and community on locus of control and self-esteem of the study subjects which further showed that male students were more internally oriented and they possessed high self-esteem in comparison to female students. Again, tribal students were externally oriented as well as they possessed low self-esteem than their non-tribal counter parts.

Sahu, K. \& Singh, D. (2011) study on "psychological well-being and self-esteem in professional college students." Result denoted that these professional students shoved above average level of psychological well being and self-esteem. Further, there was not any significant gender difference regarding the self-esteem and psychological well-being of these professionals. Both male and females exhibited above average level of psychological well- 
being and self-esteem. Income has significant effect on the psychological well-being as well as self-esteem of the subjects.

High income group showed high self-esteem and better psychological well-being. In addition the subjects of service class group indicated better psychological well-being in comparison to business class group. But there was not any remarkable differences regarding self-esteem of business group and service group.

Joshi, S. and Srivastava (2009) study on "self-esteem and academic achievement of Adolescents." The result indicated that there were on significant difference with regard to selfesteem of rural and urban adolescents. There were significant differences with regard to academic achievement of rural and urban adolescents. Urban adolescents scored higher in academic achievement as compared to rural adolescents. Boys would score significant higher on self-esteem as compared to girls. Significant gender differences were found in academic achievement. Girls were significantly higher on academic achievement as compared to boys.

Dong, Q., Koper, R. J. and Collaco, C. M. (2008) study on "social intelligence, self -esteem and intercultural communication sensitivity." They examined relationship between self-esteem and intercultural communication sensitivity. Result support hypothesized relationships and indicate a statistically significant relationship between social intelligence (SI) and intercultural communication sensitivity (ICS), with SI accounting for more than $10 \%$ of the variance in ICS. In addition, both dimensions of self-esteem i.e. self worth and self efficacy. Were significantly related to ICS, accounting for a additional $4 \%$ of the variance.

Diaman topoulou, Rydell \& Henricsson (2008) study on "self-esteem in children." Result showed that both low levels of global self-worth and exaggerated but disputed self-esteem were related to aggression. The findings indicate that, depending on low self-esteem in conceptualized aggressive children may appear to have both a low and a high self-esteem. Regarding gender differences, exaggerated self-esteem was more strongly related to aggression in boys than girls.

\section{METHODOLOGY}

The study was conducted in 300 adolescent ( 161 Boys and 139 girls) within the age group of 14-17 years. The sample was collected from three schools in and around Lucknow ( U.P.). The Schools are as follows :

- Army Public School

- Up Sainik School

- Lucknow Public Collegiate

The sample size was 300 adolescence, all of them were adolescents and were in the age group of 14-17. Out of 300 students 161 boys and 139 girls were chosen for the study. An introductory session was carried out for all the students to emphasize the need of academic achievement or flexibility, as it represents students' ability to deal effectively with setbacks, challenges and pressures in school setting. A 'Participatory Appraisal Method' was adopted, in which adolescent respondents were made to interact freely without any apprehension and to discuss about their academic pressure and the importance of scholastic performance. As a result of changing socio-economic environment in the Indian society, adolescents are exposed to various emotional issues. Academic performance of adolescents is considered to be a key to seek entry into numerous professional and vocational programmes, leading to a career choice. The competitive world is putting additional pressure on academic performance since academic scores open possible doors for further professional pursuits and realization of goals and ambitions. While some students cope with the adversities with achievment, many students do 
not have the necessary achievment attributes to overcome adversities. Students were introduced with several concepts of academic achievment, so that they better participate in the interaction.

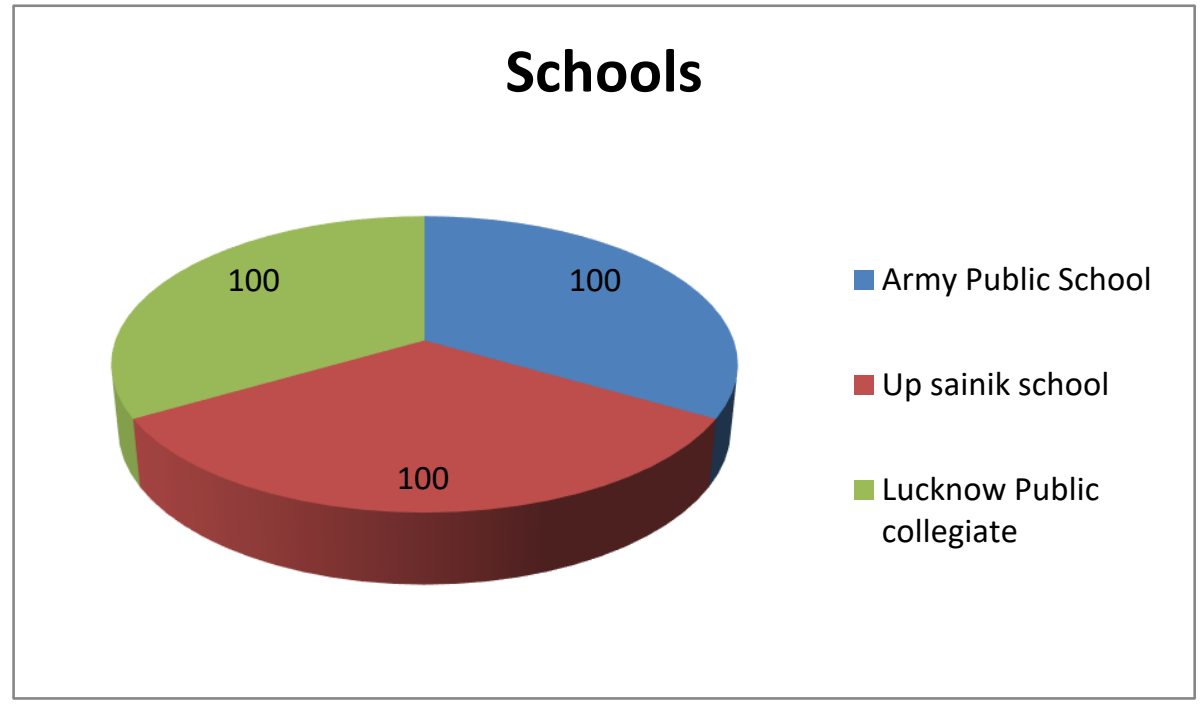

Figure 1

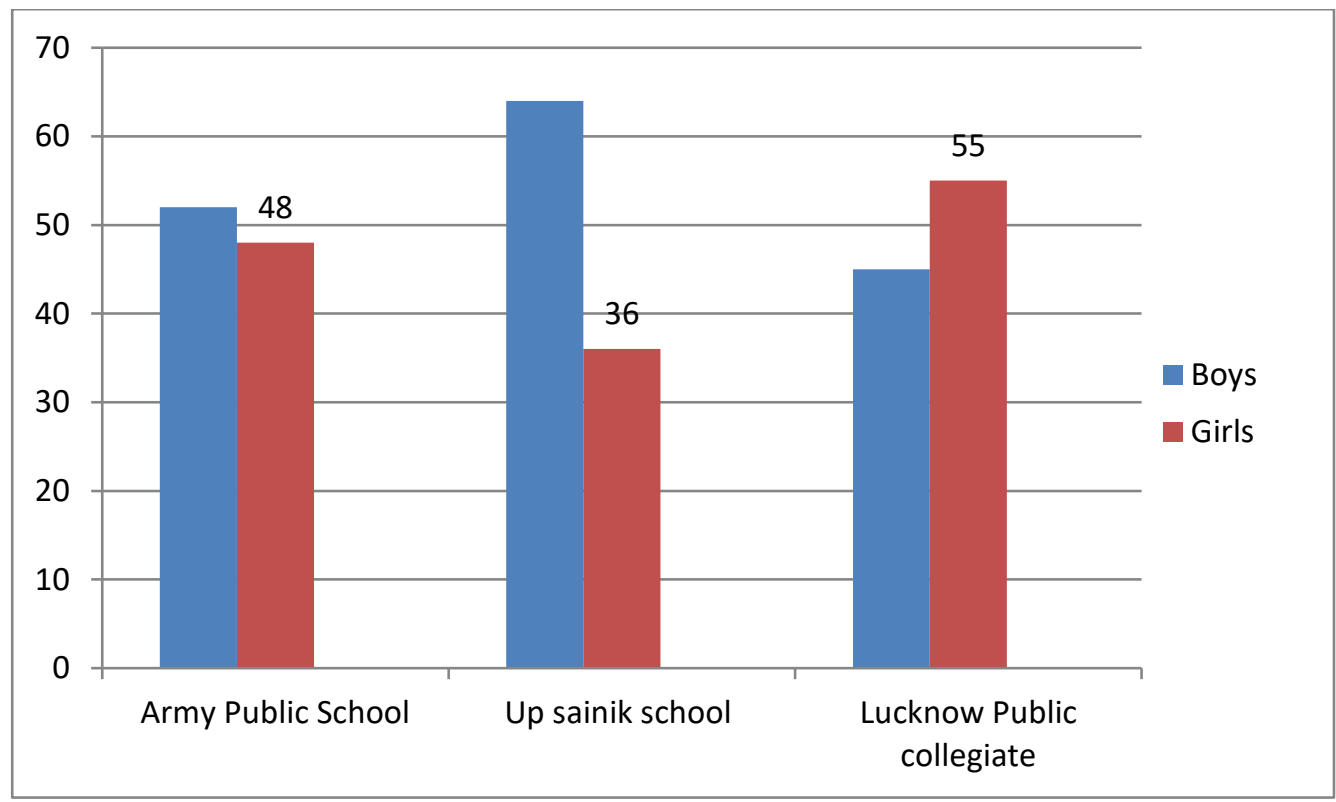

Figure 2

\section{Test and Tools}

Following standardized tests and tools were used :

- Self esteem scale ( Rosenberg, 1985)

- Academic scores and grades of adolescents .

The Parameter of the study is as follows:

INSTRUCTIONS: "Read each statement carefully and then assign a number depending upon whether you strongly agree, agree, disagree and strongly disagree with what is said: 3= Strongly Agree , 2= Agree , $1=$ Disagree , $0=$ Strongly Disagree.

1. I feel that I am a person of worth, at least on an equal plane with others.

2. I feel that I have a number of good qualities. 
Self-Esteem and its Impact on Academic Achievement among Adolescents in and around Lucknow (U.P.) India

3. All in all, I am inclined to feel that I am a failure.

4. I I am able to do things as well as most people.

5. I feel I don't have much to be proud of.

6. I take a positive attitude towards myself.

7. On the whole, I am satisfied with myself.

8. I wish I could have more respect for myself.

9. I certainly feel useless at times.

10. At times I think I am no good at all.

Phase II

For Phase II- 62 respondents found low on Trait Meta Mood and who were willing to be a part of intervention plan were taken .

\section{RESULTS \& DISCUSSION}

\section{The Result of the Study is as follows:}

\section{Self Esteem}

T-Test

\begin{tabular}{|c|c|c|c|c|c|c|}
\hline self_esteem_total & Post Test & 62 & 15.9242 & 3.30557 & .41981 & \multirow{2}{*}{1.683} \\
\hline & Pre Test & 62 & 15.0000 & 2.78756 & .35402 & \\
\hline
\end{tabular}

$* \mathrm{p}<.05$ level of significance

$* * \mathrm{p}<.01$ level of significance

During the assessment $\mathrm{T}$ test was calculated. In case of self-esteem, it is not giving a significant T-test result. Approximately Similar values were occurred. There were minimal changes occurred.

\section{Academic Achievement}

\section{Group Statistics}

\begin{tabular}{|l|l|l|c|c|c|c|}
\hline \multirow{2}{*}{ AAS } & $\begin{array}{c}\text { Experimental } \\
\text { Condition }\end{array}$ & N & Mean & Std. Deviation & Std. Error Mean & t \\
\cline { 2 - 6 } & Post test & 62 & 70.8548 & 12.55394 & 1.59435 & $2.101^{*}$ \\
\hline
\end{tabular}

$* \mathrm{p}<.05$ level of significance

$* * \mathrm{p}<.01$ level of significance

Significant differences have occurred on the variables among the pre and post test scores of the experimental group. Therefore, we can conclude that the intervention is successful.

\section{CONCLUSION}

During the study, a major problem inherent in the measures of self-esteem is the extent to which self-reports are influenced by self-presentational concerns. The available measures seem to be contaminated with social desirability. Student are guided by a strong, fundamental desire for self-esteem. People claim credit for success but deny blame for failures. They exaggerate and overestimate their abilities. Students, systematically choose to compare themselves with others who are less gifted or worse off than themselves. They deny or conceal their shortcomings and advertise their virtues and positive traits. They identify themselves with successful groups and 
distance themselves from failing or stigmatized groups. It is suggested to administer a social desirability scale along with the self-esteem questionnaire. Then, it is hopeful to reach a statistical formula to add a score of the social desirability scale to the self-esteem measure to suppress the participant's attempt to make favourable impression.

- Adolescents, who have high self-esteem are socially at ease, more confident of their own opinions and judgments. They are more ambitious, more academically successful

- Adolescents with low self-esteem view interpersonal relationship as threatening, feel less positively toward others and are easily hurt by criticism, lack confidence in their own judgments and opinions, expect others to reject them and their ideas, and have little faith in their ability to achieve, they have lower goals, less active ,appear more depressed and unhappy, more frequently manifest symptoms of anxiety, poor adjustment.

- Low self-esteem as a key factor in the development of various psychological problems i.e. loneliness, anxiety, depression and aggression.

- There is significant positive relationship between Self -esteem and academic achievement suggesting that high Self -esteem is important factor and strengthen the prediction of academic achievement in Adolescents.

Adolescents spend a lot of time and energy on academic performance, thus it is necessary for them to have high self -esteem

\section{SUGGESTIONS}

- Identify the core factors that cause low self-esteem and simultaneously identify the domains of competence that are important to the adolescence.

- Focus on sources of emotional support and social approval that exist in the adolescent's world.

- Increase self-esteem through emphasizing achievement of specific skills and goals, and by encouraging initiative.

- Support coping with difficult situations and trying to overcome them, rather than avoiding them.

\section{REFERENCES}

[1] Anwar, E. (2013). A correlational study of academic achievement and study habits: Issues and concerns. Excellence International Journal of Education and Research, 1(2), 46-51.

[2] Bagongon, C.K. and Edpalinanad, C.R. (2009). Research Proposal on the Effect of Study Habits on the Academic Performance of Freshmen Education Students in Xavier University, CaGayan Deoro City.

[3] Deb, M. and Grewal, H. P. (1990). Relationship between Study Habits and Academic achievement of undergraduate home science final year students. Indian Educational Review, 25 (3), 71-74.

[4] Dr. Umender Malik. A Comparative Study of Job Satisfaction among Government and Private Secondary School Teachers in relation to Educational Qualications, Paripex Indian Journal Of Research, Vol:2, Issue:11. 2013.

[5] Baumeister, R.F. (1982).Self-esteem, self presentation and future interaction: A dilemma of reputation. Journal of personality, 50, 29-45.

[6] Baumeister, R. F. (1993). Understanding the inner nature of self esteem. In R.F. B a u m e i s t e r (Ed.), Self - esteem: the puzzle of low self regard (pp. 201-218). New York: Plenum. Carlson, C., Uppal, S., \& Processer, E. C. (2000). 
Self-Esteem and its Impact on Academic Achievement among Adolescents in and around Lucknow (U.P.) India

[7] Ethnic differences in processes contributing to the self-esteem of the early adolescents girls. Journal of early adolescence, 20, 44-67.

[8] 38 Self-Esteem and Academic Achievement Devi , T. K. \& Prasanti (2004). Self concept of adolescents in urban and rural areas.

[9] Indian Psychological Review, 62, 202-206 Dornbusch, S. M., Ritter, P. L., Leiderman, P. H., Roberts, D. F. \& Fragligh, M.J. (1987).

[10] The relation of parenting style to adolescent school performance. Child Development, 58, 12441257.DuBois, D. L., Burk- Braxton, C., Swenson, L. P.,Tevendale, H. D., \& Hardesty, J. L., (2002).

[11] Race and gender influences on adjustment in early adolescence: Investigation of an iterative model. Child development, 73, 1573-1592.Devi T Kayani \& Prasanti. (2004).

[12] Self concept of adolescents in urban and rural areas. Indian Psychological Review, 62, 202-206. Eccles, J. S. (1987).

[13] Gender roles and achievement pattern : an expectancy value perspective. In J. N. Reinisch L.A. Rosenblum \& S. A. sanders (Eds.), Masulinity/ Femininity: Basic Perspective (pp. 240-280).

[14] New York:Oxford University Press.Gecas, Viktor. (1982).

[15] The self-concept. Annual Review of Sociology.1-33.Good, C.V. (1973).

[16] Dictionary of education. II edition, Mc Graw Hill Book company. INC, New York. Grewal, H.P., \& Dunteman, G.H.(1964).

[17] Relationship of achievement motivation and academic performance of rural and urban high school students. Indian Psychological Review, 32, 1-5.Harter, S. (1986).

[18] Processes underlying the construction, maintainers, and enhancement of self-concept in children. In J. Suls \& A. G Greenwald (Eds.), Psychology Perspectives of self, (pp. 136-182), Hillsdale, NJ : Erlbaum. Harter, S. (1996).

[19] Historical roots of contemporary issues involving self concept. In B. A. Bracken (Ed.), Handbook of self - concept (pp.1-37).New York: Wiley.

[20] Housley, K., Martin, S., McCoy, H., \& Greenhouse, P. (1987).

[21] Self-esteem of adolescents males related to race economic status and area of residence. Perceptual and Motor skill, 64, 559-566.Huitt, W. (2004).

[22] Becoming a Brilliant Star: An introduction. Presentation at the Forum for Integrated Education and Educational Reform sponsored by the Council for Global Integrative

[23] Education, Santa Cruz, CA. Available on at http://chiron.valdosta.edu/ whuitt/brilstar/chapters/BrilStarintro.pdf Keltikangas- J. L. (1990).

[24] The stability of selfconcept during adolescence and early adulthood: a 6-year follow-up study. Journal of General Psychology, 11, 361-368.Kling, K. C., Hyde, J. S., Showers, C. J. \& Buswell, B. N. (1999).

[25] Gender differences in selfesteem, a meta-analysis. Psychological Bulletin, 125, 470500.Manning, M. A., Bear, C. G. \& Minke, K.M. (2006).

[26] Self-concept and self-esteem. In G.G. Bear \& K.M. Minke (Eds.)., children's need III: Development, prevention and intervention (pp.341-356). Washington, DC: National association of school psychologist. Markstrom, C. A., Marshall, S.K., \& Tryon, R. J.(2000).

[27] Resiliency, social support and coping in rural low income Appalachian adolescents from two racial groups. Journal of adolescence, 18, 145-172.Nathaniel, B.(1994).

[28] The Six Pillars of Self-Esteem, New York: Bantam, Nathaniel, B. (1992). 
[29] "What Is Self-Esteem?" in Student Self-Esteem: A Vital Element of School Success, Volume 1, ed. Garry R. Walz and Jeanne C. Bleur (Ann Arbor, Michigan: Counseling and Personnel Services, Inc.,1992), p. 18.O’Brien, E. J., \& Epstein, S. (1998).

[30] The Multidimensional Self-esteem Inventory. Odessa, FL: Psychological Assessment Resources, Inc.Prashant, A. \& Arora, M. (1988).

[31] Psychological stress in adolescents: a study of depression, self esteem and physical symptoms Unpublished. Ph.D Thesis. Banaras Hindu University.Reasoner, R.(2005).

[32] The true meaning of selfesteem. Retrieved November 4th from international council for selfesteem. Robins, R. W., Trzesniewski, K. H., Tracy, J. L.,Gosling, S. D., \& Potter, J. (2002).

[33] Global selfesteem across the life span. Psychology and Aging, 17, 423-434.Shobhna Joshi and Rekha Srivastava 39 Rosenberg, M. (1965).

[34] Society and adolescents self image. Princeton, NJ: Princeton University press. Rosenberg, M. (1979).

[35] Conceiving the self. New York: Basic Books. Rosenberg, M (1985).

[36] Self-concept and psychological well - being in adolescence. In R. L. Leahy (eds.), The Development of the self (pp. 205-246). Orlando, FL Academic Press.Rosenberg, M. (1986).

[37] Self-concept to middle childhood to adolescence. In J. Suls (eds),Psychological perspectives on the self,(pp.107-136). Hillsdale, NJ : Erlbaum. Rosenberg, M. (1990).

[38] The self-concept: Social product and social force. Social Psychology: Sociological Perspectives, 593-624.Rosenberg, M., Carmi, S., \& Carrie, S. (1995).

[39] Global self-esteem and specific self-esteem. American sociological Review, 141-156. Roscigno, V. J., \& Crowley,J. L. (2001).

[40] Rurality, institutional disadvantage, and achievement /attainment. Rural Sociology, 66, 268298. Sekaran, U. (1983).

[41] Factors influencing the quality of life in dual career families. Journal of Occupational Psychology, 56, 161-174 Singh, D. (1970).

[42] Academic achievers and non achievers: An analysis of some factor associated with success and failures in university education. Allahabad: United Publishers.Tinku, A. N. \& Biswas, P. C. (1994). Student's involvement in studies to prolonged Deprivation. Psychologic: An International

[43] Self - esteem, academic selfconcept and academic achievement : how the learning environment moderate thy dynamics of self concept. Journal of Personality \& Social Psychology, 90, 334349. Uma Devi, Sudha Devi \& Venkatramaiah (1988).

[44] Selfesteem: its conceptualization and measurement. Sage.Wylie, R.C. (1979). 